\title{
EARLY STUDY OF BIOCHARCOAL QUALITY FROM POULTRY LIVESTOCK WASTE
}

\author{
Dwi A. Anggorowati ${ }^{*}$, Faidliyah N. Minah ${ }^{2}$, Anis Artiyani ${ }^{3}$, Lalu Mustiadi ${ }^{4}$ \\ ${ }^{1,2}$ Department of Chemical Engineering, Faculty of Industrial Technology Industri, \\ Institut Teknologi Nasional, Malang, Indonesia \\ ${ }^{3}$ Department of Environmental Engineering, Institut Teknologi Nasional, Malang, Indonesia \\ ${ }^{4}$ Department of Mechanical Engineering, Institut Teknologi Nasional, Malang, Indonesia
}

*Corresponding Email: ana_anggorowati@ lecturer.itn.ac.id

\begin{abstract}
Bio charcoal is one type of fuel in the form of charcoal made from various kinds of biological or biomass material, which includes agricultural waste, forestry waste, agro-industrial waste, animal waste from livestock waste. Bio charcoal is produced from the carbonization process or the charcoal process of materials containing carbon (biomass). One of the biomasses that has the potential to be used as raw material for bio charcoal is poultry manure originating from poultry livestock waste. The composition of poultry livestock waste (chicken manure) is crude protein by $9.97-12.67 \%$ and crude fiber by 30.36-32.65. This study aims to determine the optimal carbonization temperature and particle size in the carbonization process so that optimal Fixed Carbon level can be obtained by using variations in the size of Chicken Manure Particles, namely: 30 mesh, 40 mesh, 50 mesh, and Charcoal temperature: $200^{\circ}$ $\mathrm{C}, 225^{\circ} \mathrm{C}, 250^{\circ} \mathrm{C}, 275^{\circ} \mathrm{C}$ and $300^{\circ} \mathrm{C}$. Stages of the process carried out is drying chicken manure to the weight of constant chicken manure (water content $<10 \%$ ) and then mashed and sieved to sizes of 30, 40, and 50 mesh and the last stage is the charcoal process of chicken manure with variations in temperature of $200^{\circ} \mathrm{C}, 225^{\circ} \mathrm{C}, 250^{\circ} \mathrm{C}, 275^{\circ} \mathrm{C}$, and $300^{\circ} \mathrm{C}$ until the perfect charcoal process. From this study, the best parameter is obtained at $350^{\circ} \mathrm{C}$ and 50 mesh particle size with $45 \%$ Fixed Carbon content, $3.26 \%$ moisture content, $41 \%$ ash content, and volatile matter content $22 \%$.
\end{abstract}

Keywords: Bio charcoal, Fixed Carbon, Carbonization Process

\section{Introduction}

Livestock waste causes various environmental problems, pollutant generated from livestock is caused by decomposition of livestock manure, namely BOD and COD (Biological/Chemical Oxygen Demand), pathogenic bacteria, water pollution, dust, and odor pollution [1]. Chickenmanure wastes contain ammonia gas and flammable $\mathrm{H}_{2} \mathrm{~S}$. From a livestock, a broiler chicken can produce 0.15 $\mathrm{kg}$ of manure. Based on BPS data, the population of broilers in East Java in 2017 amounted to $1,698,368,741$ so that the potential to produce chicken manure was $254,755.31$ tons of chicken manure. In the process of forming carbon, chicken manure must go through a charcoal process (carbonization) [2].

The contents of compounds in chicken manure are as follows: 6\% Phosphorus, 17\% Nitrogen, 0.58\% Calcium, 9.97-12.67\% Crude Protein and 30.36-32.65 5 Crude fiber [2].

According to Cheresmisinoff (1993) in Dahlan (2013) Carbonization or charcoal is the process of heating organic materials with a certain temperature with a limited amount of oxygen [3]. This process causes the decomposition of several organic compounds such as constituents of materials such as methanol, acetic acid vapors, tartar, and hydrocarbons. The remaining material after carbonization is carbon with narrow pores.

Previous studies by Setiawati et al. [4] with the title Effect of Activator on Making Active Carbon of Coconut Shell with fixed variable of drying coconut shell under the sunlight to $10 \%$ water content, the most optimal result used $20 \%$ $\mathrm{NaCl}$ activator, $4.88 \%$ water content, $3.54 \%$ ash content, $14.63 \%$ volatile matter, and $761.07 \mathrm{mg} / \mathrm{g}$ iodine absorption [4].

A study conducted by Sumangat and Broto with the title Technical and Economical Study of Jatropha Seed Processing as a Furnace Raw Material with a particle size of a 40 mesh jatropha seed [5]. The most optimal result has $7.25 \%$ moisture content, $6 \%$ ash content, $23.75 \%$ oil content, and 4117 calories/gram calorific value. Similar to the research conducted by Asroni et al. [6] with the title Effect of Charcoal 
Formation from Variation Dimensions of Chicken Feces Particles. By determining the mass of chicken feces particles with a mass of 1000 grams, at the charcoal temperature $1255 \mathrm{C}$, and the rotating drum rotation $25 \mathrm{rpm}$, for variations in the dimensions of chicken feces particles at $(0.323,0.392,0.989,1.634) \mathrm{mm} 2$, resulting in curing time $(42,781 ; 32,086 ; 25,346$; $15,821) \mathrm{s}$, with the rate of mass formation of charcoal $(23,375 ; 31,166 ; 39,454 ; 63,207)$ grams/s. Increased lau mass formation of charcoal, caused by the surface area of particles in the heat absorption of charcoal, so that the dimensions of chicken feces particles have a clear influence on the rate of mass formation of charcoal.

In the study of Saparudin et al. [7] with the title Effect of Pyrolysis Temperature Variation on the Result Level and Calorific Value of the Mixed Briquette of Rice Husk-Chicken Manure with varying charcoal temperatures of $225^{\circ} \mathrm{C}$, $275^{\circ} \mathrm{C}, 325^{\circ} \mathrm{C}$, and $375^{\circ} \mathrm{C}$. The most optimal is charcoal at $275^{\circ} \mathrm{C}$ with a calorific value of $4252.67 \mathrm{cal} / \mathrm{gram}$, a moisture content of $1.504 \%$, a Char content of $51.12 \%$.

Some studies above discussed several topics, especially regarding chicken manure, but it still needs improvement on the most optimal process in the initial stages of the study of the process of carbonization of chicken manure so that the study aims to find out the most optimal process in the process of chicken manure carbonization. Furthermore, it can be applied to several study topics.

\section{Methodology}

\subsection{Bio Charcoal}

Charcoal is black residue containing impure carbon produced by imperfect heating/burning to remove water content and volatile components from animals or plants. Charcoal is black, light, easily destroyed, and resembles coal consisting of $85 \%$ to $98 \%$ carbon, the rest is ash and other chemical elements [7].

Bio charcoal can be made from faeces of all types of livestock, even according to Setiawan [8], the energy produced from burning wood is $3,300 \mathrm{kcal} / \mathrm{kg}$ while the energy produced from burning bio charcoal can reach $5,000 \mathrm{kcal} / \mathrm{kg}$.
Table 1 Charcoal quality requirements based SNI 01-6235-2000

\begin{tabular}{ll}
\hline Parameter & Score \\
\hline Water Content & Max. 8\% \\
\hline $\begin{array}{l}\text { The missing part in heating } \\
\text { of } 950^{\circ} \mathrm{C}\end{array}$ & Max. 15\% \\
\hline Ash Content & Max. 8\% \\
\hline
\end{tabular}

\subsection{Experimental}

The study was conducted at the Chemical Engineering Research Laboratory of S1 ITN Malang. The permanent variable used in this study was the mass of dried chicken manure = 100 grams, the water content in chicken manure was less than $10 \%$. Meanwhile, the changeable variable used was the Charcoal Temperature by $200^{\circ} \mathrm{C}, 225^{\circ} \mathrm{C}, 250^{\circ} \mathrm{C}, 275^{\circ} \mathrm{C}$, and $300^{\circ} \mathrm{C}$ and the size of chicken manure particle by 30,40 , and 50 mesh.

\subsection{The Materials and Equipment}

Material used in this study was chicken manure and equipment used for the study were gloves, burners (furnaces), digital scales, porcelain cups, 30, 40, and 50 mesh sieves, stirrers.

\subsection{Study Procedure}

The stages of the process carried out in the charcoal process are drying chicken manure that has been taken from the previous cage until the weight of the dried chicken manure becomes constant (water content $<10 \%$ ) then smoothing chicken manure by pounding it then sifting in sizes of 30, 40, and 50 mesh and the last stage is the process of chicken manure charcoal with temperature variations of $200^{\circ} \mathrm{C}, 225^{\circ} \mathrm{C}, 250^{\circ} \mathrm{C}$, $275^{\circ} \mathrm{C}$, and $300^{\circ} \mathrm{C}$ with the size of chicken manure particle: 30,40 , and 50 mesh to the perfect charcoal process.

\section{Results and Discussion}

\subsection{Charcoal Yield}

A yield analysis is carried out to determine the results of the charcoal obtained after the carbonization process. The following is a graph 
of the relationship between charcoal yield and charcoal temperature:

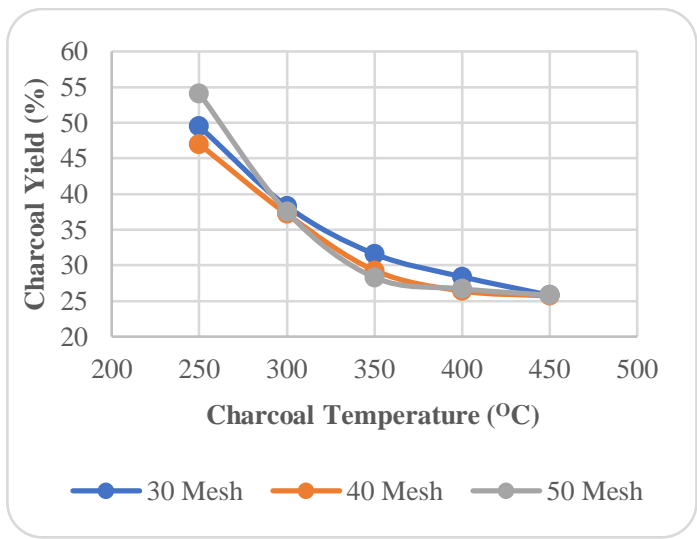

Figure 1 The Relationship Between Charcoal Temperature and Particle Size Towards Charcoal Yield

It can be seen in Figure 1that there was a decrease in the Charcoal Yield in chicken manure with variations in temperature of $250^{\circ} \mathrm{C}$, $300^{\circ} \mathrm{C}, 350^{\circ} \mathrm{C}, 400^{\circ} \mathrm{C}$, and $450^{\circ} \mathrm{C}$ and sizes of 30, 40, 50 mesh. From the picture above, the higher the carbonization temperature and the smaller the particle size, the yield will decrease.

From the chart above, the best Charcoal Yield is at $250^{\circ} \mathrm{C}$ and a size of 50 mesh with the result of $54.1 \%$. According to Sukiran et al. [9] the higher the carbonization temperature, the more substances contained in the material will be decomposed so that the charcoal formed will be less. The yield of charcoal is also influenced by the particle size of chicken manure, according to Asroni et al. [10] from the results of his research the increased rate of mass formation of charcoal, caused by the surface area of the particles in the heat absorption of charcoal.

So are yield is also influenced by ash content, the more ash content, the less yield will be. The higher the carbonization temperature and the smaller the particle size, the more material is burned so that the ash produced will increase and the yield will decrease.

\subsection{Water Content}

Analysis of Water Content is carried out to find out the water content in carbon. If the water content is getting bigger, the carbon quality will decrease because it will reduce the level of bound carbon or fixed carbon. The following is a chart of the relationship between water content and charcoal temperature:
From Figure 2., there was a decrease in water content in charcoal with temperature variations of $250^{\circ} \mathrm{C}, 300^{\circ} \mathrm{C}, 350^{\circ} \mathrm{C}, 400^{\circ} \mathrm{C}$, and $450^{\circ} \mathrm{C}$ and sizes of $30,40,50$ mesh. From the picture above, the higher the carbonization temperature and the smaller the particle size, the water content produced will decrease. The lowest water content results obtained at a temperature of $450^{\circ}$ $\mathrm{C}$ and sizes of 30,40 , and 50 mesh with a moisture content of $1 \%$. The highest water content results obtained at a temperature of $250^{\circ}$ $\mathrm{C}$ and sizes of 30, 40 mesh with a moisture content of $4.95 \%$. All variables are in accordance with SNI 01-6235-2000 for water content which is a maximum of $8 \%$.

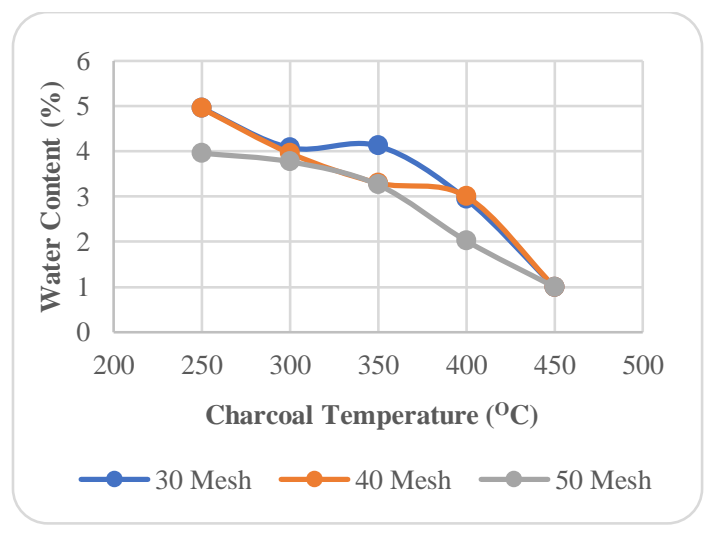

Figure 2 The Relationship between Charcoal Temperature and Particle Size Towards Water Content

The higher the temperature and the smaller the mesh size, the more perfect the combustion process will be so that more water will be evaporated. According to Martunis [11], the smaller the particle size, the lower the water content. This is because the smaller the particle size, the wider the surface area so that the porosity of the material will be higher, and the evaporation of water will be greater.

\subsection{Ash Content}

Ash content is a parameter used to determine ash quality. If the ash content is low, the quality of charcoal will be higher. The following is the results of the analysis of ash content:

Based on Figure 3, there was a decrease in ash content in charcoal with temperature variations of $250^{\circ} \mathrm{C}, 300^{\circ} \mathrm{C}, 350^{\circ} \mathrm{C}, 400^{\circ} \mathrm{C}$, and $450^{\circ} \mathrm{C}$ and sizes of 30,40 , and 50 mesh. From the chart above, the higher the carbonization temperature and the smaller the particle size, the higher the ash content produced. From the analysis results of the lowest ash 
content is at the carbonization temperature of $250^{\circ} \mathrm{C}$ at the size of 30 mesh with $20 \%$ ash content, the highest ash content is at the carbonization temperature of $450^{\circ} \mathrm{C}$ at the sizes of 30, 50 mesh with $52 \%$ ash content. All variables do not comply with SNI 01-6235-2000 for ash content which is a maximum of $8 \%$.

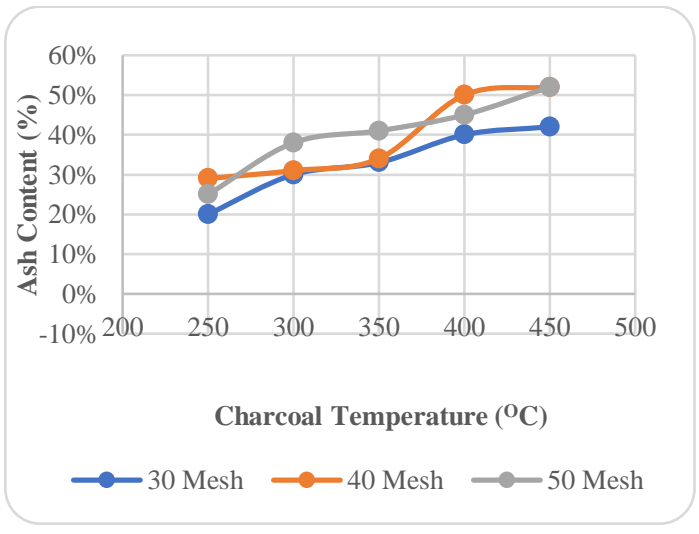

Figure 3. The Relationship Between Charcoal Temperature and Particle Size Towards Ash Content

From the Figure 3 above, the higher the temperature and the smaller the particle size, the ash content will increase. This is because when the carbonization temperature is higher, the combustion process of the material will be more perfect so that the more ash is formed. Ash is the remaining part of the combustion process in which the main constituent is silica minerals [12]. If the impurity in the material is higher, the ash content will be higher especially the mineral content which cannot be burned or oxidized by oxygen such as $\mathrm{SiO} 2, \mathrm{Al}_{2} \mathrm{O}_{3}, \mathrm{Fe}_{2} \mathrm{O}_{3}, \mathrm{CaO}$, and alkali. According to Sulistyanto [13] the smaller the particle, the faster the material will be burnt because the porosity and surface area of the material is getting bigger.

\subsection{Volatile Matter Content (Flying Substance Level)}

Volatile Matter or Flying substance level is a substance that can evaporate as a result of the decomposition of compounds that still exist in charcoal other than water such as $\mathrm{CO}, \mathrm{CO}_{2}, \mathrm{CH}_{4}$, and $\mathrm{H}_{2}$. Volatile Matter is also a parameter used to determine the quality of charcoal. The lower the Volatile Matter content, the better the quality of charcoal. The following is the results of the content analysis of Volatile Matter:

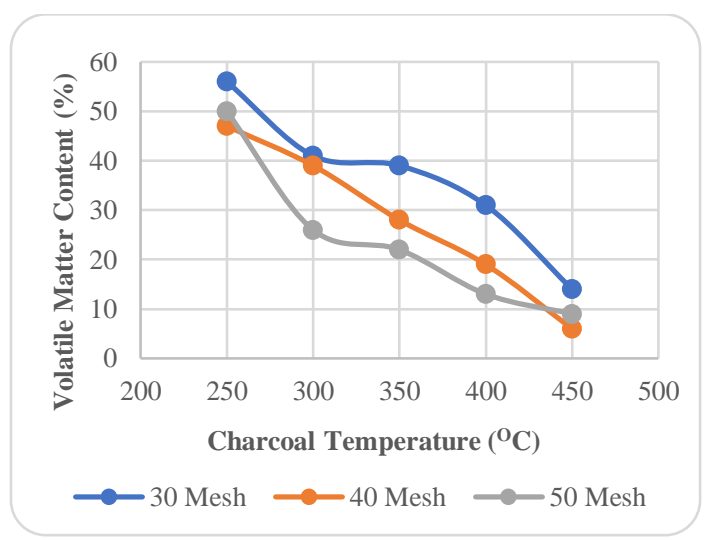

Figure 4. The Relationship Between Charcoal Temperature and Particle Size Towards Volatile Matter Content

From the analysis result above, in general, the higher the temperature and the smaller the particle size, the Volatile Matter Content will decrease. The lowest result was obtained at $450^{\circ}$ $\mathrm{C}$ and the size of 40 mesh with a Volatile Matter Content of $6 \%$. The highest result is obtained at a temperature of $250^{\circ} \mathrm{C}$ and the size of 30 mesh with a Volatile Matter Content of $56 \%$. Volatile Matter Content according to SNI 01-6235-2000 is at a temperature of $400^{\circ} \mathrm{C}$ with a particle size of 60 mesh and at a temperature of $450^{\circ} \mathrm{C}$ with particle sizes of 30, 40, 60 mesh. Everything is in accordance with SNI, no more than $15 \%$.

If the carbonization temperature is higher, the more materials will be evaporated so that the Volatile Matter will decrease. The height of volatile matter content is caused by the low temperature of decomposition of non-carbon compounds such as $\mathrm{CO}, \mathrm{CO}_{2}, \mathrm{CH}_{4}$, and $\mathrm{H}_{2}$ are not perfect, causing many non-carbon compounds left in the material [14].

High evaporated substance content will cause a lot of smokes during the combustion process, especially high-value CO gas so it is not good for health and the environment.

\subsection{Fixed Carbon Content}

Fixed Carbon is the most important parameter used to determine the quality of charcoal. Fixed Carbon is obtained from the accumulation of yield, water content, ash content, and Volatile Matter. The following is a Fixed Carbon analysis in this study:

The best Fixed Carbon content is at $350^{\circ} \mathrm{C}$ and the size of 50 mesh. Fixed Carbon is influenced by factors of water content, ash content, and Volatile Matter. If the water content, 
ash, Volatile Matter are getting smaller, the quality of charcoal will be better.

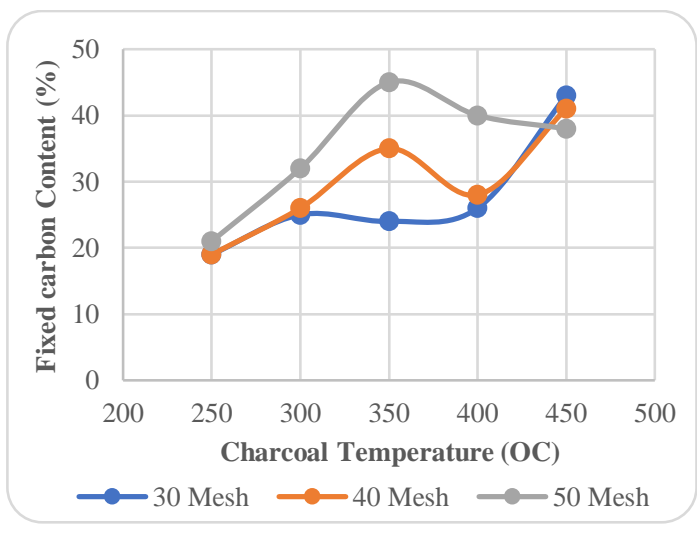

Figure 5. The Relationship Between Charcoal Temperature and Particle Size Towards Fixed

\section{Carbon Content}

The magnitude of Fixed Carbon is strongly influenced by the amount of ash, water content, and Volatile Matter content [15]. If the ash content, moisture content, and Volatile Matter content are high then Fixed Carbon will be smaller. Conversely, if the ash content, water content, and Volatile Matter content are low, then Fixed Carbon will be higher.

\subsection{Image of Surface Structure Morphology (SEM)}

One of the characteristics that can describe the surface morphology of chicken manure particles is by using Scanning Electron Microscopy (SEM). The surface structure morphology describes the surface shape, texture, and porosity of the surface. This characterization uses 2 samples, namely chicken manure with and without charcoal process. The difference from the characteristics of the chicken manure particles will be clearly seen.

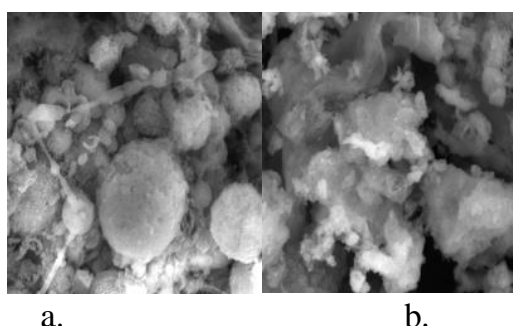

Figure 6. Comparison of the SEM result of Chicken Manure (a) before the charcoal process (b) after the charcoal process

SEM images after the charcoal process were taken from samples that have the best carbon fix levels, namely the charcoal temperature at 350
${ }^{\circ} \mathrm{C}$ and 50 mesh particle size. From the picture it can be seen that after the charcoal process the carbon particles have a very rough surface which confirms that it belongs to the amorphous group.

\section{Conclusions}

Based on the study, the best result is the chicken manure charcoal carbon fixed content of $45 \%$ at $350^{\circ} \mathrm{C}$ and 50 mesh particle size with $3.26 \%$ moisture content, $41 \%$ ash content, and $22 \%$ volatile matter content.

\section{Suggestions}

When the charcoal comes out of the furnace or after the carbonization process is completed, it must be cooled immediately because if it is in contact too long with air, the charcoal will convert into ash.

\section{References}

[1] Haryati, Tuti. 2006. Biogas: Animal Husbandry Waste That Is an Alternative Energy Source, Bogor: Animal Research Institute.

[2] Saparudin, Syahrul, and Nurchayati. 2015. The Effect of Pyrolysis Temperature Variation on Yield and Heat Value of Briquette Mixes with Rice Husk Chicken Manure. Mechanical Engineering Dynamics, ISSN: 2088-088X Vol.5 No. 1.

[3] Dahlan., M Hatta. 2013. The Use of Activated Carbon from Moringa Seeds Can Purify Cooking Oil. Palembang: Chemical Engineering Department, Sriwijaya University Faculty of Engineering.

[4] Setiawati, Evi., Suroto. 2010. Effect of Activator Material on Coconut Shell Activated Carbon. Banjar Baru Industrial Baristand Researcher.

[5] Sumangat, D., and Broto, W., 2009, Technical and Economical Study of Jatropha Seed Meal Briquette as Fuel Furnace, Journal of Agricultural Post Harvest Technology Bulletin, 5 (1), 18-26.

[6] Asroni M., Mustiadi L., Sumanto, dan Anggorowati D. A. 2018. Effect of Charcoal Formation from Variation Dimensions of Chicken Feces Particles, Procediing of National seminar of Industrial Technology Innovation and APPLCATION 
2018, ISSN 2085-4218, 86-89, ITN Malang.

[7] Saparudin, Syahrul, and Nurchayati. 2015. The Effect of Pyrolysis Temperature Variation on Yield and Heat Value of Briquette Mixes with Rice Husk Chicken Manure. Mechanical Engineering Dynamics, ISSN: 2088-088X Vol.5 No. 1.

[8] Setiawan, 2007, Utilize Livestock Manure, Solution to Environmental Problems and Utilization of Alternative Energy, Penebar Swadaya Publisher.

[9] Sukiran, M., Azri, Loh, S.K., Bakar, N.K.A., and May, C.Y. 2011, Production and Characterization of Bio-Char from the Pyrolisis of Empty Fruit Bunches, American Journal Of Applied Sciences, 8(10), 984-988.

[10] Asroni M., Mustiadi L., Sumanto, and Anggorowati D. A. 2018. Chicken Charcoal Particle Charcoal Process with Indirect Heating. ITN Malang.

[11] Martunis, 2012, Effect of Drying temperature and time to Quantity and Quality of Potato starch variety of Granola, Journal of Technology and Indutrial of Agricultural Indonesia Vol 4, 26, 20854927.

[12] Ristianingsih Y., et al, 2015, The Effect of Temperature and The Characteristics Of Bioarang Briquette, Made From Oil Palm Empty Fruit Bunches By Pyrolysis Process, Conversion Journal. Vol, 4 (2), 45-51.

[13] Sulistyanto, Amin, 2006, The Combustion Characterristics of Bio Briquette Mixer of Coal and Coconut Coir, Journal of Engineering 2(7).

[14] Gustan P, Hendra D., 1999, Making Activated Charcoal From Oil Palm Empty Fruit Bunches, Forest Product Research Journal, 17(2), 113-122.

[15] Rosyidi, Jalal Soelaiman, 2012, Comparison of Characteristics between rice Husk-Based Briquettes as arenewable energy, Journal of Physics 15(4). 